\title{
A Description of the Girara District, Western Papua
}

\section{Author(s): W. N. Beaver}

Source: The Geographical Journal, Vol. 43, No. 4 (Apr., 1914), pp. 407-413

Published by: geographicalj

Stable URL: http://www.jstor.org/stable/1778373

Accessed: 05-06-2016 05:39 UTC

\section{Your use of the JSTOR archive indicates your acceptance of the Terms \& Conditions of Use, available at}

http://about.jstor.org/terms

JSTOR is a not-for-profit service that helps scholars, researchers, and students discover, use, and build upon a wide range of content in a trusted digital archive. We use information technology and tools to increase productivity and facilitate new forms of scholarship. For more information about JSTOR, please contact support@jstor.org.

The Royal Geographical Society (with the Institute of British Geographers), Wiley are collaborating with JSTOR to digitize, preserve and extend access to The Geographical Journal 
this method, by draughtsman and engraver, and it may therefore be looked at in the light of an experiment; it will, I think, be admitted that the varied surfaces are represented wonderfully well. This sample was drawn on the surveyed contourlines as engraved on the Ordnance Survey plan of Jerusalem; but the intercalation of lines, as suggested by Prof. Davis, would add very much to the beauty and accuracy of the picture. This system is scarcely applicable to maps on a smaller scale than 1:250,000; for smaller scales and for wall maps and school maps we are reduced, as Prof. Herbertion says, to the representation of masses, the broad or diagrammatic features, and these are best represented by contours and flat tints, the so-called layer system.

\section{A DESCRIPTION OF THE GIRARA DISTRICT, WESTERN PAPUA.*}

By W. N. BEAVER, F.R.G.S., F.R.A.I.

The western part of Papua (British New Guinea) has commonly been supposed still to conceal many remarkable features; it certainly contains the last remaining unknown and unexplored areas, though these are rapidly being dealt with. One of these little-known areas is that now to be described as the Girara district, because it is inhabited by people of common kinship, and speaking a common language known as Girara. The district lies between the eastern bank of the Fly river and the headwaters of the Bamu river. I was not the first person to come in contact with the people, but I am not aware that they or the district have been described elsewhere than in official reports. My own knowledge of the district covers a period of some four years.

The banks of the Fly river for over 200 miles are low-lying and swampy ; but on the eastern bank about 60 miles from the mouth of the river there is a tract with a more or less elevated shore. At one point called Gaima, where there is a village which is practically the first outlet of the Girara people to the Fly river, the bank is several feet above high-water mark, and is formed of a hard red clay, in striking contrast to the nipa-palm swamp which elsewhere borders the river. Just below Gaima-where the Fly is over 2 miles across from the shore to the nearest islands (Dugope)-a reef, of hard sand and small shells and of mud much impregnated with iron, juts right across the river. This is the only reef, as far as I know, in the lower reaches of the Fly river, with the exception of a small one about 14 miles lower down on the western shore opposite a village called Nabodai. The red clay banks extend-with breaks-from a point about 8 miles below Gaima to nearly double that distance above. The whole formation is curious and interesting. Gaima is situated on a high, rather fertile point, and the whole position is distinctly attractive.

The district was discovered in 1900, I think, by C. G. Murray, then Resident Magistrate of the Division. The natives of western Papua

* Map, p. 480 . 
have always been found to be more or less reticent as to new tribes; and it was only after much trouble that Mr. Murray was able to get guides, or indeed any information, when he was about to enter this new district. Finally, through the good offices of the Domori people who live on Domori island, and, as was later discovered, are intimately acquainted with the Girara people, Mr. Murray was able to penetrate some distance into the district and to establish a lasting friendship with its people. The district was afterwards occasionally visited by Mr. Murray's successor, Mr. A. H. Jiear, and again by nnyself.

The track followed from Gaima village led practically almost entirely in a due northerly direction from the Fly river. The land immediately bordering the bank of the river is good, and is favourable for the cultivation of coconuts and, especially, yams. The good land, however, is not of great extent; and the country through which the track leads inland becomes poorer, the timber lighter and more sparse, and the grasses of a thinner variety and poorer quality. The soil is waterlogged in the wet. season-that is to say, for nearly nine months of the year. About 5 miles from Gaima there is a huge swamp about one mile by two. It is covered by a broad-bladed long swamp grass. Such timber as is on it and in the vicinity is very stunted, and consists of a small variety of she-oak and small stringy bark (Eucalypt. robusta). In the wet season this swamp is almost impassable for foot traffic, but may be crossed by canoe. In the dry season, the traveller may sink almost to the waist in a mixture of rotten swamp grass and mud. The swamp is said to contain numbers of crocodiles, but I am informed, though I am somewhat sceptical about this, that they are not of a kind harmful to man. The women of the neighbourhood do a good deal of fishing in the swamp, which is really only one of a chain which extends for a long distance parallel to the Fly river.

For some distance onward the country is flat, consisting of wide plains covered with a short sour grass, and only broken here and there by narrow belts of timber and sago swamps. The timber is of no great size, and comprises mostly bloodwood (Eucalypt. corymbosa), red stringy bark (Eucalypt. robusta), and paper bark Ti-tree (Melaleuca leucadendron). The first village reached is called Kubu or Mida, and is prettily situated in a large grove of coconut trees. The soil over this area is generally poor, but the particular spots selected by the natives for their villages and gardens are of excellent quality. From Kubu onward the country rises somewhat, and begins to be broken by low hillocks or ridges, the general trend of which is north-east and south-west. Baia, the next village reached, is built among light forest on very low hills. These hills or ridges, I believe, form the watershed between the creeks running into the Fly river and those running into the tributaries of the Bamu to the north.

After leaving Baia the track descends somewhat and crosses a small creek called Kabiri. The natives first called this the Bamu, and led me 
to suppose-and apparently both Murray and Jiear were originally misled in the same manner-that this was the head of that river. This seemed an utter impossibility, and it was only after a good deal of questioning that I was able to place it to my satisfaction. The Kabiri, here merely a trickle, flows or rather meanders in a north-easterly direction into a large river variously known as the Aramia, or, more correctly I believe, the Apera-oromo. The Girara natives themselves call the Aramia the Bamu; but this name is very misleading. The Aramia, to refer to it by the name by which most Europeans know it, flows into the main Bamu just above the junction of the Bebea and Dibiri at the top of Sagamu island.

After leaving the ridges by Baia, the country becomes open again and after a succession of very low ridges opens out into one vast swamp. The first time that I crossed this swamp, it was all under water, the Kabiri flowing through its midst and in places was 10 feet deep. At the time of my second crossing, which was in the middle of an exceedingly dry season, I found the swamp dry and Kabiri creek itself almost in the same state.

The country was distinctly more interesting when under water, that is to say, from a picturesque point of view. The natives I had with me described it as the "sea with islands in it." As far as the eye could reach, it appeared to be nothing but swamp dotted here and there with hillocks and ridges. I might mention that these hills, some of which were 60 or 70 feet above high-water mark, proved to be very fertile and were thickly planted with coconuts and other plants of native gardens. The village sites had invariably been selected on the tops of the ridges.

On the northerly side of this depression are two large villages, Warigi and Barimo. Warigi has always existed on its present site, but Barimo, when I first visited it over four years ago, was built to the left of Warigi, and at that time the people were preparing the new communal house in its present position, known as Kakemadas. Barimo seems to be the central village of the district, and the Kabiri river flows past it to the north-east. On one trip I travelled from Barimo to Baia by canoe down this stream. Walking was impossible, the whole country being under water. To the westward of Barimo there is a series of four large villages, all built on the high ground above the swamp-level. Dadi seems to be the extreme western limit to which the Girara people have settled. To the north and east, there is still another series of villages all situated on the creeks and tributaries of the Aramia river; I have a sketch made on my last visit to the district by the chief of Barimo describing the position of these villages, and I have attached a copy to this paper. It is, of course, not geographically correct, but seems to fit in with other information I have been able to collect.

The important river system of the Aramia seems to require thorough exploration. In 1911 Messrs. Butcher and Landtmann made a hurried journey from Gaima to Barimo, there embarked in a canoe, and after two days and nights' paddling, reached the main Bamu river; but 
unfortunately the trip was so hurried that no notes were taken and no traverse of the Aramia made. Consequently nothing was achieved beyond proving what was already known, that is, that the Kabiri is a tributary of the Aramia, which again is a tributary of the Bamu river.

In visiting one or two of the villages to the north-east, Adario and Kimamo, both now abandoned, Jiear states he reached the main Bamu river which was there very small. Now at the junction of the Aworra and the Wawoi the Bamu is a very large river, and neither of these tributaries at any point shown on existing maps is as small as Jiear describes. Taking all the evidence I have been able to gather on the subject-unfortunately, Mr. Jiear made no sketch-map of his trip-both from the natives and from my own observations, I have come to the conclusion that Jiear crossed the Aramia and its tributary Kini creek, confusing it with the Bamu owing to the habit of the natives calling the Aramia by that name. Roughly, I think the course of the Aramia must be as follows: starting from its mouth at the top of Sagamu island, it runs westerly and then north-westerly and then probably westerly again. It is a question that it is highly desirable to solve.

It is said that Kabiri creek is navigable by whaleboat right up to Barimo and that the influence of the tide is felt there, though very slightly. As is well known, a very heavy bore travels up the Bamu at new and full moon, and this bore also goes very strongly up the Aramia; I have no doubt that it also makes itself felt in its tributaries. No attempt has yet been made to reach the Girara country from the Baniu side, but it should prove much easier of access than has generally been supposed.

Last year I made a fresh expedition into a previously unknown portion of the Girara district, starting this time not from Gaima, but a few miles lower down the Fly, from Taitiarato. The country was exactly of the same kind as that traversed on previous occasions. It was all low-lying, swampy, and broken by low ridges and hillocks on which the villages are built. I should say, however, the ridges were, if anything, much lower than those reached by the Gaima route; this is understandable, as of course they are nearer the sea-coast.

Some of the villages had been known by name before, but none of them had been visited and several new ones were discovered. The inhabitants were the same in every respect as those on the Gaima route; but, owing to the intervening dense sago swamps, these two sets of natives do not frequently communicate. Communication, however, is kept up with Warigi, Barimo, and one or two other villages by water, that is to say, by way of the Aramia river and its tributaries, on which both groups of villages are situated.

The accompanying sketch-map was made with watch and compass only, and is probably not strictly accurate, but will serve for practical purposes, and as an explanation of the district. The supposed course of the Aramia is shown and the supposed position of its population is shown 


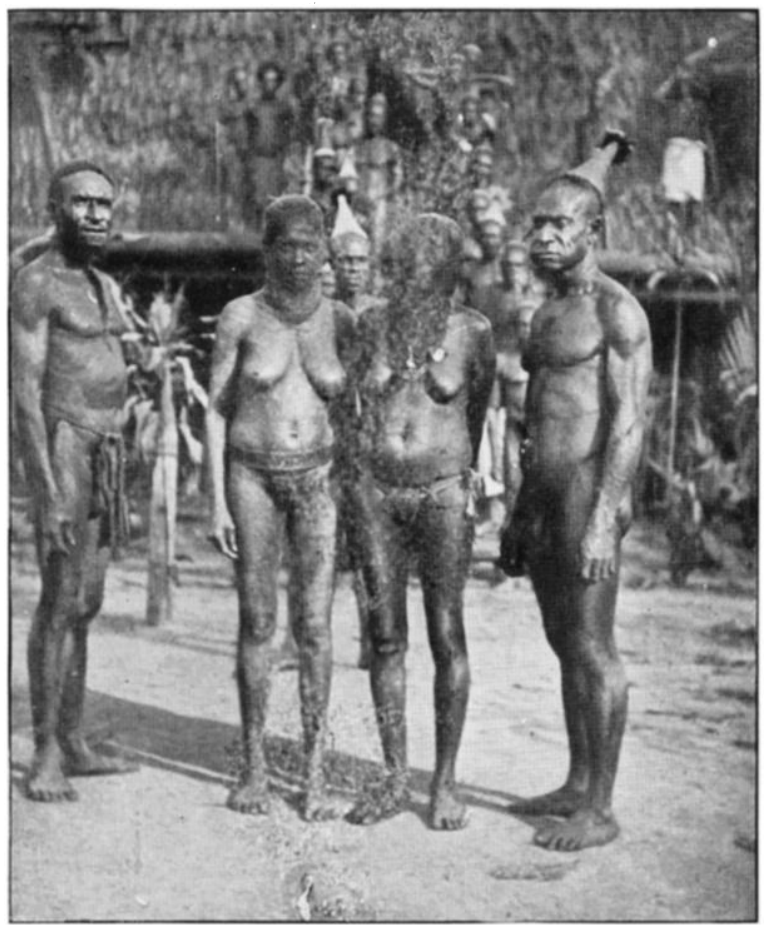

TYPES OF GIRARA MEN AND WOMEN.

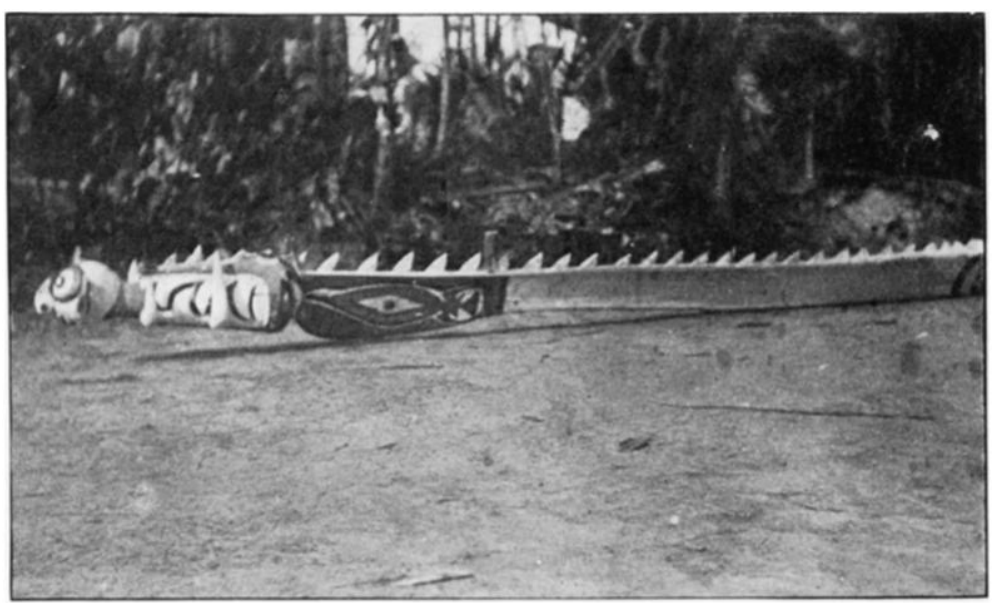

PROW OF CARVED GIRARA CEREMONIAL CANOE.

This content downloaded from 155.198.30.43 on Sun, 05 Jun 2016 05:39:49 UTC All use subject to http://about.jstor.org/terms 


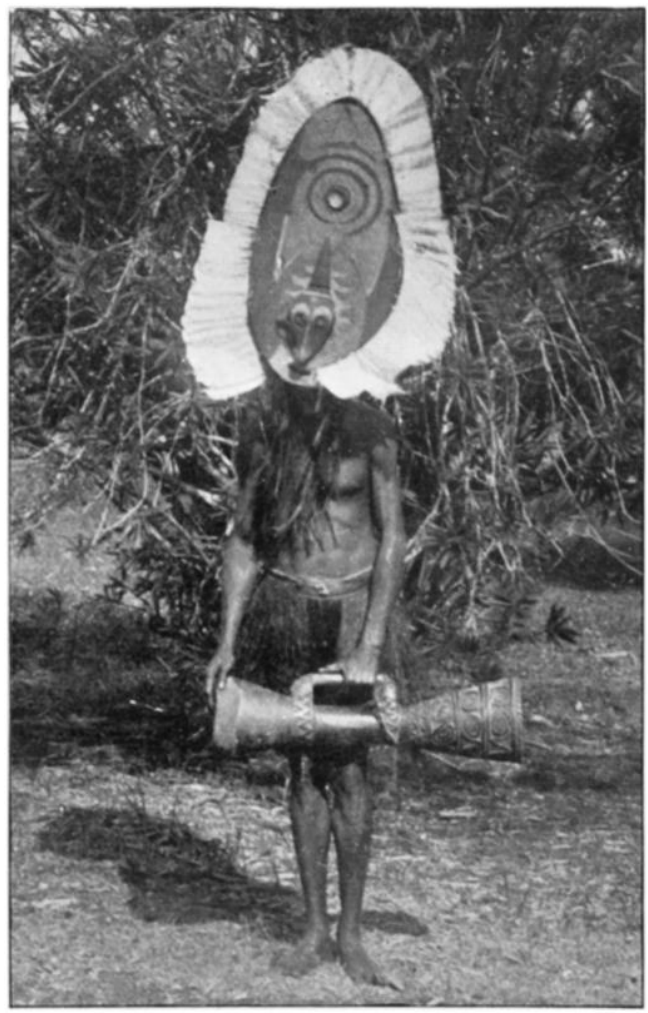

GIRARA MAN IN DANCING COSTUME.

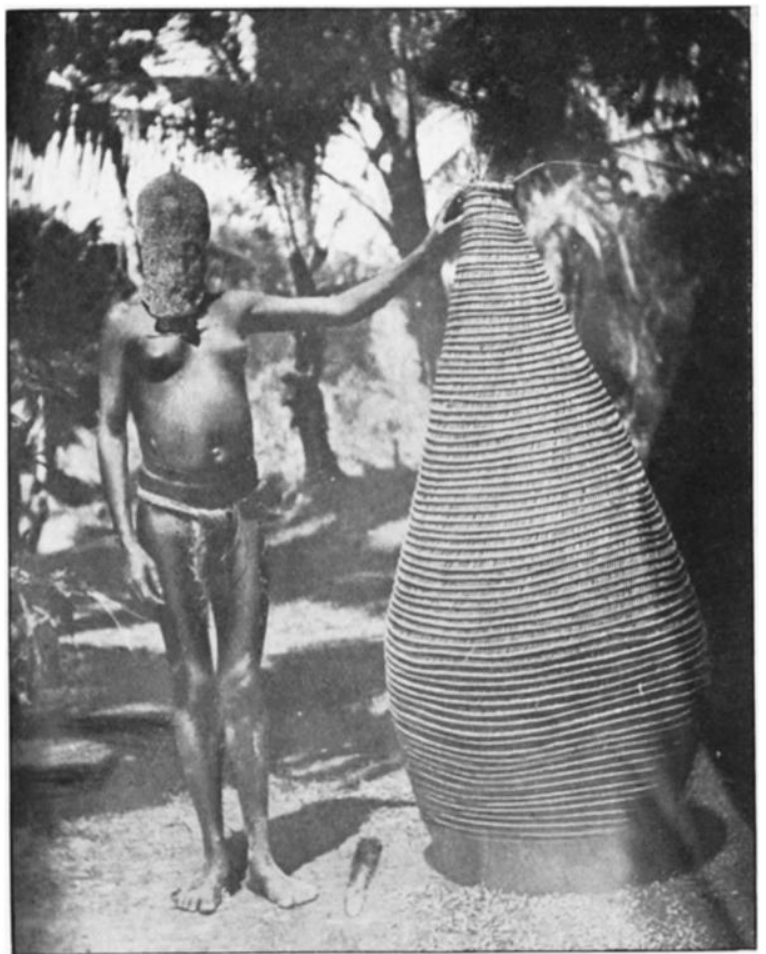

TYPE OF VEILED GIRARA WOMAN WITH FISHING POT.

This content downloaded from 155.198.30.43 on Sun, 05 Jun 2016 05:39:49 UTC All use subject to http://about.jstor.org/terms 
on the native sketch. In addition to the villages in the main Girara district, to the west of Gaima there exists one tribe who must also be included, the Akari. This section possesses a large settlement about the same distance inland as Baia and also a coastal settlement, used more particularly for the purpose of fishing.

The following is, I think, a fairly complete list of villages of a people speaking one language and with the same manners and customs : Gaima, Kubu, Baia, Warigi, Barimo, Adiba, Dogona, Iu, Dadi, Akari, Kotari, Pisi, Isoga, Adario, Burida, Wiwi, Dubosa, Uradu, Sepesepe, Kaniwa, Kabani, Tugaro, Oriomo, Bege. The total estimated population would be between 6000 and 7000 . Closely-I am not sure how closely-akin to the Girara people are the tribes of Domori and Pagona, situated on the bank of the Fly river. Legend undoubtedly gives all three the same ancestors, but it is noteworthy that the dialects of the Domori and the Girara differ.

I am not prepared to offer any theories as to the racial origin of the Girara people; but it is certain that their language is Papuan, not Melanesian nor Papuo-Melanesian. The people themselves say that, not far from Gaima, a man married a dog and had as offspring, three sons, the two elder of whom settled at Domori and Pagona, and were the ancestors of the people of those places, whereas the youngest, having quarrelled with his elder brothers, went inland where he saw that the country was good, and decided to make a village. In spite of their dog ancestry, this animal, as far as I am aware, is not the totem of any of them, their totems being five in number: the pig (Itira), the pigeon (Boboa-I think this is the Goura pigeon), the alligator (Dupa), the cassowary (Goragora), and the snake (Amura). The totems were first given out to the people by a hero-ancestor called Ibari. The totem customs do not differ materially from those of other western tribes, and are patrilinear.

The alligator and the pig seem to figure largely in the tribal life of their people, well-carved representations of the former appearing on the canoe prows and of the latter on the house steps.

The Girara people are of medium sturdy stature, and seem tolerably healthy, although skin disease (tinea imbricata), yaws, and a good deal of elephantiasis occur. Most of the men wear a conical fibre hat decorated with feathers and painted with red ochre and a white paint made of lime; others wear skull caps of network. The hair is shaved back, showing a high narrow forehead, and a small corkscrew goatee beard is worn (ene). The women cover the head, face, and bosom with a veil of net, which is stated to be a mourning dress. The other dress is scanty and consists of a long tail of coloured grass woven on to a plaited cane belt, draws tightly between the legs and tucked in the belt again behind. Neither sex tattoo, but cicatrices are in some instances raised. This practice is almost universal in the west, and especially in the Fly and Bamu river districts, 
The chiefs have a little authority. The late chief of Barimo, combining the dual functions of chief and sorcerer, was, as far as I saw, the one man in the west implicitly obeyed by his people. A chief is succeeded by his brother, not his son, and the son succeeds after the death of his uncle. Polygamy is the rule, the number of wives occasionally being 14 or 15 . Divorce is uncommon.

Each village usually consists of a single large communal house, although in places I have seen women's houses as well. The central part of the house, which is from 15 to 20 feet wide or more, is allotted solely to the men, as are also the doors at each end. The only occasion on which women use these doors is during the ceremony attending the dedication of a new house. At each side of the central space are tiers of cubicles, two deep and two or three high. These are approached by ladders, and are used by the women and children, having entrances from the side. The dimensions of Dogona house are $500^{\prime} \times 117^{\prime} \times 70^{\prime}$. Surrounding the house is a large courtyard, through which wide roads planted with crotons, dracaenas and other bright shrubs, lead up to the house in the centre. Close alongside the walls are planted betel nut palms (Areca); then comes the open square, and beyond that again a dense row of coconuts. The open spaces are always kept scrupulously clean, and are very pleasing to the eye.

Sago and fish are roasted in sago leaves or in canes, and, with coconuts, form the staple diet. There are huge fields of sago and coconuts wherever it is possible to plant. Other vegetables used as food are taro and yams. Potatoes and bananas are not largely cultivated, chiefly because the area of suitable land is not very great. They are planted in beds and protected from the sun with shade sheds. Sprouting coconuts are protected in the same way, and the intelligence of these people in their methods of agriculture is indeed of a high order. They are head hunters, but not cannibals.

Betel nut mixed with lime is chewed day and night with something almost approaching ceremonial. The lime is obtained from the coast, to which trading expeditions are made to buy shells for the purpose of burning. No man seems fully dressed without his bag of chewing gear.

Thr general bent of the people is decidedly artistic, perhaps almost more artistic than that of any other people I have met with in New Guinea ; but I am inclined to think that their art is associated in some degree with a phallic order.

Theidistrict is rich in bird and animal life. As might be expected in a region which is three parts swamp, there is a great variety of waterfowl. There are two species of ibis, and a species each of crane, duck, and shag. I found three pigeon, the Goura, the Torres Straits, and a large blue variety which is very good eating. Birds of Paradise (Raggiana) abound, and there are flocks of cockatoos, parrots, and parrakeets. Of game birds I saw snipe and plover, and on the grass plains considerable numbers of quail of two kinds. In the bush there is abundance of black cassowary. 
The commonest animals are the wild pig, yellow cuscus, and small flying phalanger. The two latter are often kept as pets.

As pointed out previously, the timber generally is poor ; but I noticed particularly one very long straight tree from which the native torches are made. It has a peculiar aroma, and burns with a bright clear light. I take it to be a kind of tallow-wood.

For the greater part of the year the usual mode of travelling across country is by canoe. The work put into these canoes is very fine. They are long and very narrow in the beam in order to allow of progress through the swamps. The paddles, which are long and lance-shaped with a rib on each side of the blade, are artistically decorated with colours which resist the water-the pigments are, I think, red and yellow ochres.

The fish in the swamps is of poor quality and small. The women are very expert at fishing. They use either a net on a cane frame, something like a butterfly net, or else a large trap made of black cane, looking very like a lobster-pot. These traps are from 5 to 7 feet high.

Among other products very fine tobacco is grown by the natives and put up in rolls. This is traded principally with Domori on the Fly river.

The principal weapon is the bow, which is made of black palm. The arrows are of the usual western type, and are not particularly striking. Three varieties of stone club have been seen, the star, the disc, and the pineapple; but stone clubs are rare in a region where one may travel for many miles without seeing a stone. A wooden club, usually of the pineapple type and made of a very hard brown wood, is in more general use.

The drums are of decidedly original type, and on certain ceremonial occasions a drum some 7 feet in length is used. This is held by one man and beaten by a second with a wooden mallet. The head of the drum is of wallaby skin.

Finally, so little is known both of the Girara district and its people that further exploration would certainly be richly repaid.

\section{DR. MAWSON'S RETURN.}

Dr. Mawson's enforced detention, with six companions, on the inhospitable shores of the Antarctic continent, has happily reached an $t$ d, he and his party having been brought back in safety to civilization by the Aurora, Captain J. K. Davis, towards the end of February. The iurora reached Port Adelaide, South Australia, in the late afternoon of February 26, and Dr. Mawson at once sent to the Times a telegram summarizing the scientific results of his expedition, and in particular giving a vivid description of the disastrous journey on which his two companions, Lieut. Ninnis and Dr. Merz, unhappily lost their lives, while the leader himself struggled

No. IV.-APRIL, 1914.] 


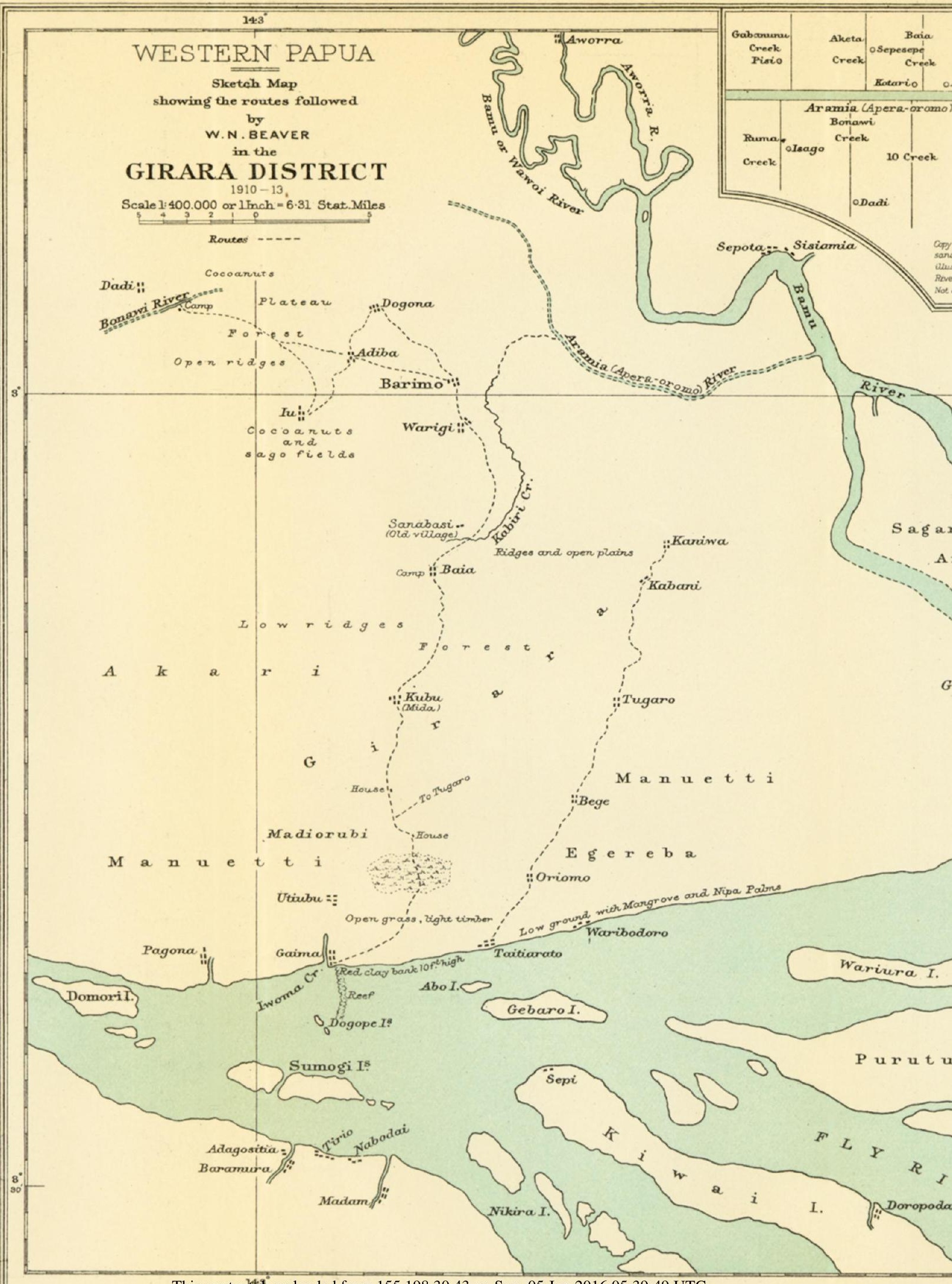




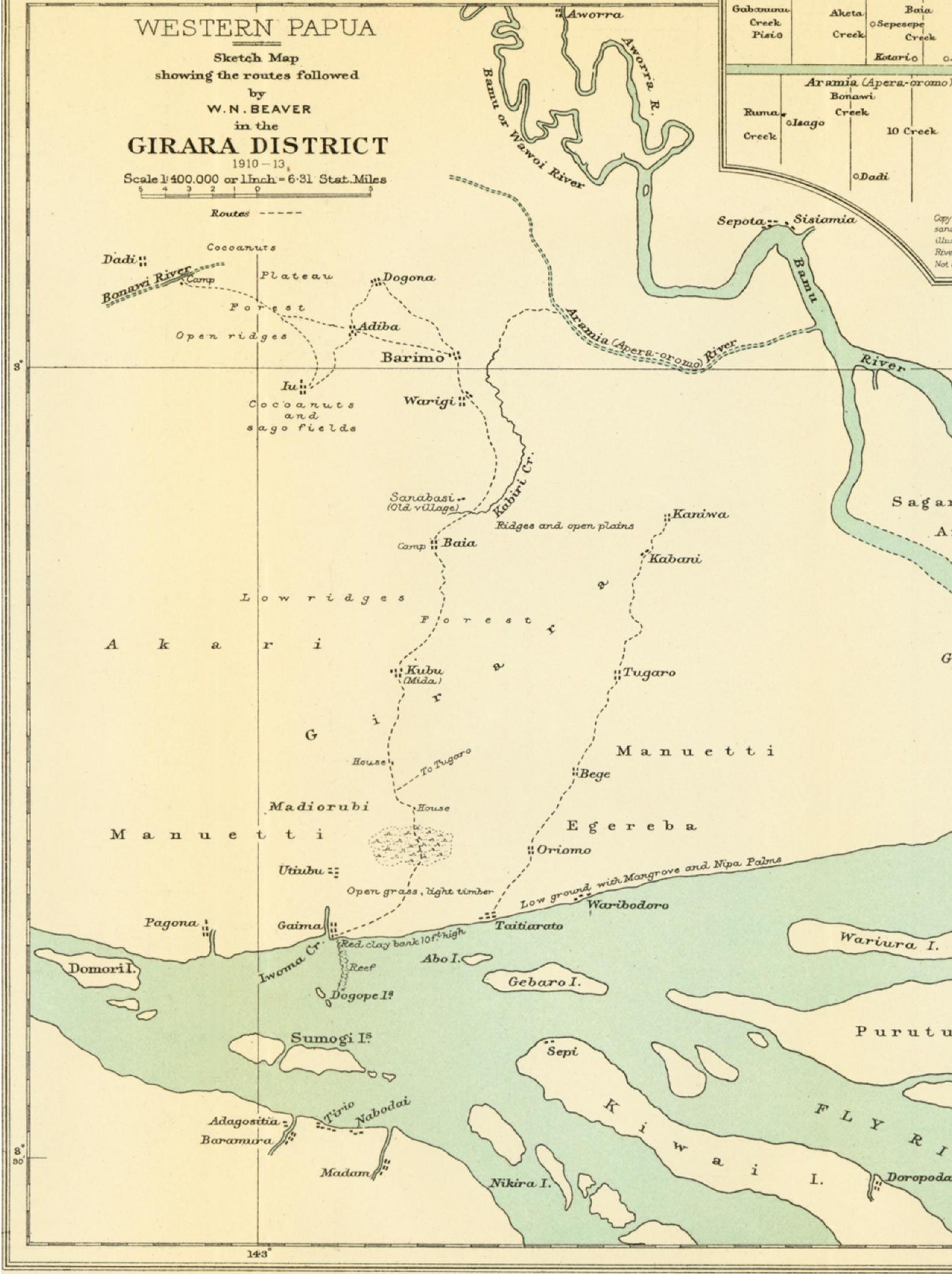

Published by the Royal Geographical Society 


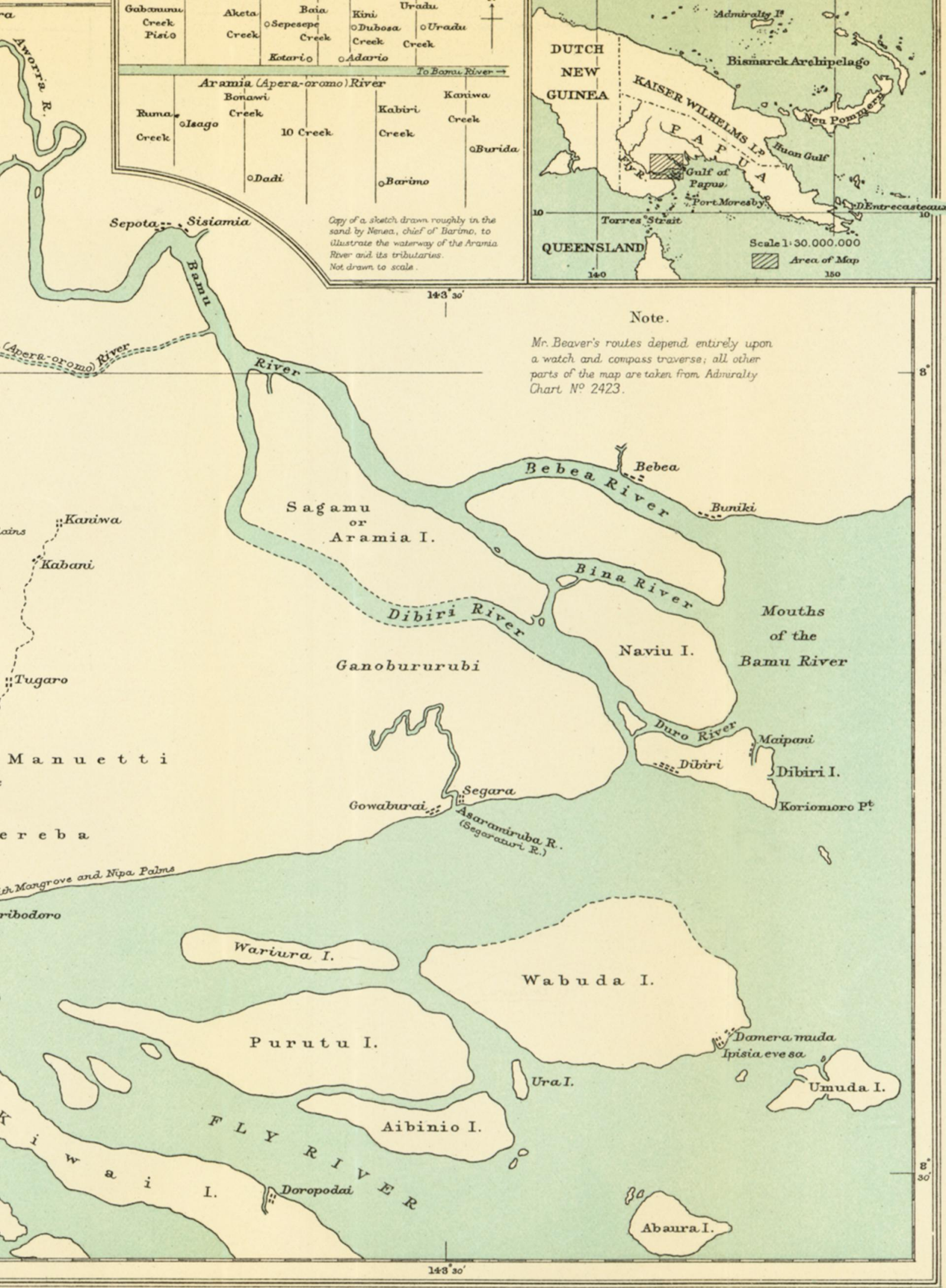

